\title{
HUBUNGAN ANTARA UMUR, JENIS KELAMIN, PENDIDIKAN DAN PEKERJAAN DENGAN STIGMATISASI TERHADAP ORANG DENGAN HIV/AIDS DI RSUD MGR. GABRIELMANEK,SVD ATAMBUA
}

\author{
Pius A. L. Berek *) \\ Wendelina Bubu*) \\ *) Program Studi Keperawatan Universitas Timor Kampus Atambua, Jl. Wehor Kabuna \\ Haliwen, Atambua Nusa Tenggara Timur. Post 85711. Email: \\ francis_domin2012@yahoo.com. Phone: +6281280426042
}

\begin{abstract}
ABSTRAK
Permasalahan HIV / AIDS sejak lama menjadi isu bersama yang terus menyedot perhatian berbagai kalangan diseluruh dunia. HIV/AIDS merupakan masalah global yang melanda dunia sejak awal dekade 80 - an. Begitu banyak isu legal yang terjadi dalam perawatan pasien HIV / AIDS yang menimbulkan banyak stigma yang berbentuk prasangka buruk dan mendiskreditkan atau menolak ODHA.. Penelitian ini merupakan penelitian desktriptif analitik korelasi menggunakan pendekatan cros sectional dengan tujuan untuk menganalisis hubungan antara umur, jenis kelamin, pendidikan dan pekerjaan dengan stigmatisasi bagi ODHA di RSUD Mgr. Gabriel Manek, SVD Atambua. Teknik sampling accidental sampling terhadap 170 responden dengan kriteria inklusinya adalah pengunjung di RSUD Mgr. Gabriel Manek, SVD Atambua, bisa baca tulis dan bersedia menjadi responden. Teknik analisis univariat untuk menganalisis terhadap tiap variable. Terdapat $61,2 \%$ responden yang memberi stigmatisasi bagi ODHA bagi ODHA di RSUD Mgr Gabriel Manek SVD Atambua. Sedangkan analisis bivariat menggunakan chi square dengan derajat kepercayaan $95 \%(\alpha=0,05)$ ditemukan tidak terdapat hubungan antara umur dengan stigmatisasi bagi ODHA di RSUD Mgr Gabriel Manek SVD Atambua (p value $=0,433$ ), demikian juga jenis kelamin, tidak terdapat hubungan yang signifikan ( $p$ value $=0,429$ ). Namun pendidikan dan pekerjaan ditemukan adanya hubungan yang bermakna yaitu orang yang berpendidikan rendah (SD dan SLTP) memiliki peluang 2,23 kali lebih besar kemungkinan untuk memberikan stigmatisasi bagi ODHA dibandingkan dengan orang yang berpendidikan Lanjutan sampai perguruan tinggi ( $\mathrm{p}$ value $=0,028$; $\mathrm{OR}=2,23 ; 95 \% \mathrm{CI}=1,04-4,45$ ); dan orang yang tidak bekerja memiliki kemungkinan 1,42 kali memberikan stigmatisasi bagi ODHA dibandingkan dengan orang yang bekerja ( $\mathrm{p}$ value $=0,007 ; \mathrm{OR}=1,42 ; 95 \% \mathrm{CI}=0,22-0,78$ ). Disarankan kepada manajemen rumah sakit agar meningkatkan penyebaran informasi melalui program PKRS secara tersentral. Untuk peneliti selanjutnya agar mengembangkan penelitian yang serupa untuk melihat variabel mana saja yang paling berhubungan.
\end{abstract}

Kata Kunci: Stigmatisasi, ODHA, HIV/AIDS 


\title{
RELATIONSHIP BETWEEN AGE, GENDER, EDUCATION AND WORKING WITH STIGMATIZATION ON PEOPLE LIVING WITH HIV/AIDS IN MGR GABRIEL MANEK, SVD ATAMBUA HOSPITAL
}

\author{
Pius A. L. Berek*) \\ Wendelina Bubu *) \\ *) Nursing Program at University of Timor Atambua Campus, Jl. Wehor Kabuna \\ Haliwen, Atambua East Nusa Tenggara. Post 85711. Email: \\ francis_domin2012@yahoo.com. Phone: +6281280426042
}

\begin{abstract}
The problem of HIV/AIDS has long been a shared issue that continues to attract the attention of various groups throughout the world. HIV/AIDS is a global problem that has hit the world since the early 80s. So many legal issues that occur in the care of patients with HIV/AIDS that cause a lot of stigma in the form of prejudice and discredit or reject PLWA. This research is a descriptive analytical correlation study using a cross sectional approach with the aim to analyzing the relationship between age, sex, education and work with stigmatization for PLWHA in Mgr Gabriel Manek, SVD Atambua Hospital. The accidental sampling technique of 170 respondents with inclusion criteria was visitors at Mgr Gabriel Manek, Atambua SVD Hospital, can read and write and is willing to be a respondent. Univariate analysis techniques to analyze each variable. There were $61.2 \%$ of respondents who gave stigmatization for PLWHA in the Gabriel Manek SVD Atambua Hospital. Whereas bivariate analysis using chi square with $95 \%$ confidence level $(\alpha=$ 0.05 ) was found that there was no relationship between age and stigmatization for PLWHA in Gabriel Manek, SVD Atambua Hospital ( $\mathrm{p}$ value $=0.433$ ), as well as gender, there was no relationship ( $\mathrm{p}$ value $=0.429$ ). However, education and work found a significant relationship, namely those with low education had a chance of 2.23 times more likely to stigmatize PLWHA compared to people who had advanced education to tertiary education ( $\mathrm{p}$ value $=0.028 ; \mathrm{OR}=2.23 ; 95 \% \mathrm{CI}=1.04-4.45)$; and people who don't work have a possibility of 1.42 times to stigmatizing PLWHA compared to people who have working ( $\mathrm{p}$ value $=0.007 ; \mathrm{OR}=1.42 ; 95 \% \mathrm{CI}=0.22-0.78$ ). It is recommended to hospital management to increase the spread of information through the PKRS program centrally. For future researchers to develop similar research to see which variables are most related.
\end{abstract}

Keywords: Stigmatization, PLWHA, HIV / AIDS 


\section{PENDAHULUAN}

HIV atau Human Immunodeficiency Virus merupakan virus yang melemahkan sistem kekebalan tubuh manusia. AIDS adalah singkatan dari Acquired Immuno Deficiency Syndrome, yang merupakan sekumpulan gejala penyakit yang disebabkan oleh penurunan sistem kekebalan tubuh karena serangan HIV. Permasalahan HIV/AIDS sejak lama menjadi isu bersama yang terus menyedot perhatian berbagai kalangan diseluruh dunia, terutama sektor kesehatan. HIV / AIDS merupakan masalah global yang melanda dunia sejak awal dekade 80-an, (BKKBN, 2014). Begitu banyak isu legal yang terjadi dalam perawatan pasien. Perawatan pasien dengan HIV/AIDS menimbulkan banyak masalah sulit, salah satunya adalah mengenai stigma terhadap Orang Dengan HIV/AIDS (ODHA). Stigma adalah prasangka memberikan label sosial yang bertujuan untuk memisahkan atau mendiskreditkan seseorang atau sekelompok orang dengan cap atau pandangan buruk. Stigma adalah bentuk prasangka yang mendiskreditkan atau menolak seseorang atau kelompok karena mereka dianggap berbeda dengan diri kita atau kebanyakan orang (Ardhiyanti, 2015). Stigma terkait HIV/AIDS adalah segala prasangka, penghinaan dan diskriminasi yang ditujukan kepada ODHA serta individu, kelompok atau komunitas yang berhubungan dengan ODHA tersebut. Keadaan-keadaan ini akan menimbulkan stres bagi ODHA. Stres psikososial-spiritual pasien terinfeksi HIV berlanjut, akan mempercepat kejadian AIDS dan bahkan meningkatkan angka kematian. Jika stres mencapai tingkat exhausted stage dapat menimbulkan kegagalan fungsi sistem imun, yang memperparah keadaan pasien dan mempercepat kejadian AIDS. Modulasi respons imun akan menurun secara signifikan, seperti aktivitas APC (makrofag); Th1 (CD4); IFN; IL-2; Imunoglobulin A, G, E dan Anti-HIV. Penurunan tersebut akan berdampak terhadap penurunan jumlah CD4 hingga mencapai 180 cells/ $\mu \mathrm{L}$ per tahun (Kurniawati, 2009).

Kasus HIV / AIDS didunia mencapai 39,4 juta orang yang dikelompokkan menjadi kelompok dewasa sebanyak 37,2 juta orang, dan anak - anak dibawah usia 15 tahun sebanyak 2,3 juta orang (KemenkesRI, 2007). Di Asia terutama di Filipina kasus infeksi HIV / AIDS sangat mengkhwatirkan karena terjadi peningkatan. Akhir tahun 2016 sekitar 10.500 warga Filipina terinfeksi HIV. Hal ini juga terjadi di Indonesia, dimana berdasarkan hasil laporan Kementerian Kesehatan Republik Indonesia 2015, terjadi kecenderungan peningkatan jumlah kasus HIV dari tahun ke tahun. Pada tahun 2013 pengidap HIV sebanyak 29.037, dan AIDS sebanyak 10.163; pada tahun 2014 pengidap HIV sebanyak 32.711, AIDS sebanyak 5.494 dan pada tahun 2015 pengidap HIVsebanyak 17.325 dan sebanyak AIDS 1.238 kasus (Kemenkes RI, 2015). Di NTT kumulatif kasus HIV/AIDS sejak bulan Desember 2012 terdapat 1918 kasus, HIV positif terjaring sebesar 837 kasus dan AIDS sebesar 1081 kasus, yang meninggal sebesar 443 kasus dan 8 kasus diantaranya ditolak oleh keluarga (KPAD NTT, 2013). Menurut KPAN (2011), kasus AIDS Indonesia sebesar 26.483. Terdapat 45,9\% usia 20 - 29 tahun. Ini merupakan usia yang sangat produktif (KPAN, 2011).

Menurut Fredericson dan Kanabus (2007), sejak pertama kali ditemukan penyakit HIV/AIDS didunia pada tahun 1981, berbagai respon seperti ketakutan, penolakan, stigma dan diskriminasi telah muncul. Stigma digambarkan sebagai cap buruk yang sangat memojokan seseorang dimata orang lain. Stigma tentang HIV/AIDS telah tersebar secara cepat, menyebabkan terjadinya kecemasan dan prasangka negatif terhadap ODHA. Dengan status sebagai ODHA banyak diantara penderita yang mengucilkan diri sendiri. Sikap dan pandangan masyarakat terhadap ODHA sangat buruk sehingga melahirkan permasalahan serta tindakan pelanggaran Hak Asasi Manusia (HAM) bagi ODHA dan keluarganya. Umumnya ODHA memiliki konsep pengetahuan yang rendah tentang test HIV dan kurang juga memahami tentang eksistensi virus HIV. Semakin kurangnya pengetahuan ini akan semakin menyebabkan seseorang mengucilkan diri (Fauk et al., 2018). Selanjutnya penelitian lainnya menemukan bahwa tidak ada hubungan antara umur dengan tingkat pengetahuan remaja tentang HIV/AIDS $(\mathrm{p}=$ 0,591 pada alfa 0,05) namun terdapat hubungan yang bermakna antara jenis kelamin dengan tingkat pengetahuan remaja tentang HIV/AIDS dengan $\mathrm{p}=0,010$ pada alfa 0,05 . (Berek et al., 2018).

Stigma dan diskriminasi masih menjadi 
masalah didalam upaya pengendalian HIV/AIDS di Indonesia. Hal ini disebabkan karena ketakutan, kurangnya pengetahuan dan prasangka yang menciptakan stigma serta diskriminasi pada ODHA. Masyarakat hanya mengetahui HIV/AIDS itu sebatas penyakit menular dan penderitanya berbahaya dan belum memahami secara benar cara penularannya. Ketidakpahaman ini menyebabkan timbulnya sikap berlebihan yang tidak mendukung kehidupan ODHA.

Stigma pada ODHA menghambat proses sosialisasi, bahkan dalam hal pengobatan penderita tersebut. Akibatnya ODHA sering didiskriminasi dan cenderung dikucilkan oleh keluarga, teman-teman disekitar lingkungan tersebut. Pada sisi lain mereka juga mengalami diskriminasi dalam pelayanan kesehatan, pendidikan dan hak-hak lainnya. Lebih lanjut, stigma mempengaruhi kehidupan ODHA dengan menimbulkan depresi dan kecemasan, rasa sedih, rasa bersalah, dan perasaan kurang bernilai. Selain itu stigma menurunkan kualitas hidup, membatasi akses penggunaan layanan kesehatan, dan mengurangi kepatuhan terhadap antiretroviral (Ardani \& Handayani, 2017). Sebagaimana penelitian yang dilakukan oleh Tae et al (2019) tentang kepatuhan minum obat ARV di Puskesmas Wedomu ditemukan $12,5 \%$ responden tidak patuh minum obat ARV. Selanjunya menurut Eka (2012) stigma juga menyebabkan ODHA tidak ingin berkonsultasi, menolak mendapatkan pelayanan kesehatan serta takut untuk membuka status. Dibeberapa Kabupaten, penderita HIV/AIDS mengambil obat di kabupaten lain karena alasan malu dengan keluarga dan masyarakat disekitar. Sikap stigma manyarakat Nusa Tenggara Timur terhadap ODHA sudah ada sejak tahun 1997 ketika penderita HIV/AIDS asal Adonara pulang dari Malaysia sebagai TKI, keluarganya merasa malu dan mengucilkannya sampai penderita itu meninggal (Hati, 2017).

Banyak upaya yang telah digalakkan baik oleh Pemerintah maupun pihak swasta untuk menekan stigma masyarakat terhadap ODHA dengan cara penyuluhan-penyuluhan tentang HIV/AIDS dan pencegahannya, dukungan keluarga, kelompok-kelompok kerja sosial, dukungan teman sebaya remaja, dan lain-lain. Namun upaya-upaya ini masih saja belum berdampak baik, sebagaimana salah satu penelitian yang ditemukan oleh Berek, et al (2018) dimana ditemukan bahwa tidak ada hubungan yang signifikan antara umur remaja dengan pengetahuan tentang HIV/AIDS. Stigmatisasi bagi ODHA tetap saja terjadi sehingga berdampak bagi ODHA untuk lebih memilih menyiksa diri sendiri dengan tidak mau atau tidak mau kontrol diri, tidak patuh minum obat secara teratur, mengucilkan diri dan lain sebagainya. Beranjak dari hal-hal diatas mendorong peneliti untuk menganalisis lebih dalam lagi mengenai hubungan antara umur, jenis kelamin, pendidikan dan pekerjaan terhadap ODHA di RSUD Mgr. Gabriel Manek, SVD Atambua.

\section{METODOLOGO}

Penelitian ini merupakan penelitian deskriptif analitik korelasi dengan pendekatan studi cros sectional untuk mengetahui hubungan antara umur, jenis kelamin, pendidikan dan pekerjaan dengan stigmatisasi bagi ODHA di RSUD Mgr. Gabriel Manek, SVD Atambua.

Populasi dalam penelitian ini adalah semua orang yang berkunjung ke RSUD MGR Gabriel Manek SVD Atambua pada bulan Mei 2019. Menggunakan teknik accidental sampel terhadap 170 orang yang memenuhi kriteria inklusi sebagai berikut: Bersedia menjadi responden; Pengunjung diRSUD MGR Gabriel Manek SVD Atambua dan Pengunjung yang bisa baca dan tulis. Data dikumpulkan dengan cara menyebarkan kuisioner. Analisa data menggunakan analisa univariat untuk mengidentifikasi masing-masing variabel, dan analisa bivariat chi square untuk menganalisa hubungan antara variabel independen dengan variabel dependen dengan derajat kemaknaan $95 \%(\alpha=0,05)$ dengan ketentuan jika $<0,05$ berarti Ho ditolak artinya terdapat hubungan bermakna, sebaliknya jika > 0,05 berarti Ho gagal ditolak artinya tidak ada hubungan bermakna.

\section{HASIL}

Berdasarkan hasil penelitian mengenai hubungan antara umur, jenis kelamin, pendidikan dan pekerjaan dengan stigmatisasi bagi ODHA di RSUD Mgr. Gabriel Manek, SVD Atambua didapatkan jumlah responden sebanyak 177 orang yang mengisi kuisioner dan terdapat 7 orang yang dinyatakan drop out karena pengisian yang tidak lengkap. Terhadap 170 kuisioner yang lengkap, dilanjutkan dengan analisa untuk mengidentifikasi setiap variabel secara univariat dan dilanjutkan 
dengan menghubungkan setiap variabel independen dan dependen secara bivariat, yang digambarkan sebagai berikut.

\section{a. Analisis Univariat}

Tabel 1

Distribusi Frekuensi Responden Berdasarkan Umur, Jenis Kelamin, Pendidikan dan Pekerjaan serta Stigmatisasi bagi ODHA di RSUD Mgr. Gabriel Manek, SVD Atambua (N : 170 )

\begin{tabular}{|c|c|c|c|}
\hline No & $\begin{array}{l}\text { Variabel Independen } \\
\text { dan Dependen }\end{array}$ & Frekuensi & Persentase \\
\hline $\mathrm{A}$ & $\begin{array}{l}\text { Variabel } \\
\text { Independen: }\end{array}$ & & \\
\hline $\mathrm{I}$ & Umur & & \\
\hline 1 & $\begin{array}{lcc}\leq & 54 & \text { tahun } \\
\text { (Produktif) } & \end{array}$ & 163 & 95,9 \\
\hline 2 & $\begin{array}{l}54 \text { tahun (Non } \\
\text { Produktif) }\end{array}$ & 7 & 4,1 \\
\hline & Total & 170 & 100 \\
\hline II & Jenis Kelamin & & \\
\hline 1 & Laki-laik & 73 & 42,94 \\
\hline 2 & Perempuan & 97 & 57,06 \\
\hline & Total & 170 & 100 \\
\hline III & Pendidikan & & \\
\hline 1 & $\begin{array}{l}\text { Pendidikan } \\
\text { Dasar/Menengah }\end{array}$ & 53 & 31,2 \\
\hline 2 & $\begin{array}{l}\text { Pendidikan } \\
\text { Lanjutan/Tinggi }\end{array}$ & 117 & 68,8 \\
\hline & Total & 170 & 100 \\
\hline IV & Pekerjaan & & \\
\hline 1 & Bekerja & 91 & 53,5 \\
\hline 2 & Tidak Bekerja & 79 & 46,5 \\
\hline & Total & 170 & 100 \\
\hline $\mathrm{B}$ & Variabel Dependen & & \\
\hline $\mathrm{V}$ & $\begin{array}{l}\text { Stigmatisasi } \\
\text { ODHA }\end{array}$ & & \\
\hline 1 & Ya Memberi Stigma & 104 & 61,2 \\
\hline 2 & $\begin{array}{ll}\text { Tidak } & \text { Memberi } \\
\text { Stigma } & \end{array}$ & 66 & 38,8 \\
\hline & Total & 170 & 100 \\
\hline
\end{tabular}

Berdasarkan tabel diatas dapat diketahui bahwa dilihat dari umur, 163 orang berumur kurang dari 54 tahun $(95,9 \%)$; dilihat dari jenis kelamin, terbanyak adalah perempuan yaitu sebanyak 57,06\%; dilihat dari pendidikan, terbanyak adalah pendidikan lanjutan/PT yaitu $68,8 \%$; dan dilihat dari pekerjaan, terbanyak adalah bekerja sebagai PNS/Swasta yaitu $53,5 \%$. Berdasarkan "ya" dan "tidak" memberikan stigma kepada ODHA, dari 170 orang, terdapat $104(61,2 \%)$ responden memberikan stigma dan terdapat 66 responden $(38,8 \%)$ tidak memberi stigma kepada ODHA.

\section{b. Analisis Bivariat}

Analisis bivariat dilakukan untuk mengetahui hubungan antara variabel independen (umur, jenis kelamin, pendidikan dan pekerjaan) dengan variabel dependen (stigmatisasi bagi ODHA). Karena semua data dari setiap variabel dalam bentuk data kategorik, maka jenis uji yang sesuai adalah uji kai kuadrat (Chi Square), yaitu untuk menguji beda proporsi dari kedua kelompok variabel. (Hastono, 2006). Untuk mengetahui hasil uji dari masing-masing variabel independen dengan variabel dependen, dapat dilihat pada tabel berikut ini.

Tabel 4.2

Persentasi, OR (95\% CI) dan P Value maisngmasing Karakteristik Individu dengan Stigmatisasi Bagi ODHA di RSUD Mgr. Gabriel Manek, SVD Atambua $(\mathrm{N}=170)$

\begin{tabular}{|c|c|c|c|c|c|c|c|c|}
\hline \multirow[t]{3}{*}{ Variabel } & \multicolumn{4}{|c|}{ Stigmatisasi Bagi ODH } & \multirow{2}{*}{\multicolumn{2}{|c|}{ Total }} & \multirow{3}{*}{$\begin{array}{c}\text { OR } \\
(95 \% \mathrm{CI})\end{array}$} & \multirow{3}{*}{$\begin{array}{c}\mathrm{P} \\
\text { Value }\end{array}$} \\
\hline & \multicolumn{2}{|c|}{ "Ya" } & \multicolumn{2}{|c|}{ "Tidak" } & & & & \\
\hline & $\mathrm{n}$ & $\%$ & $\mathrm{n}$ & $\%$ & $\mathrm{n}$ & $\%$ & & \\
\hline Umur & & & & & & & & \\
\hline $\begin{array}{l}\leq \\
\text { tahun }\end{array}$ & 101 & 62,0 & 62 & 38,0 & 163 & $\begin{array}{c}10 \\
0\end{array}$ & 2,17 & 0,433 \\
\hline $\begin{array}{l}>54 \\
\text { tahun }\end{array}$ & 3 & 42,9 & 4 & 57,1 & 7 & $\begin{array}{c}10 \\
0 \\
\end{array}$ & $\begin{array}{l}(0,47- \\
10,03)\end{array}$ & \\
\hline $\begin{array}{l}\text { Jenis } \\
\text { Kelamin }\end{array}$ & & & & & & & & \\
\hline$\overline{\text { Laki-laki }}$ & 42 & 57,5 & 31 & 42,5 & 73 & $\begin{array}{c}10 \\
0\end{array}$ & 0,765 & 0,429 \\
\hline $\begin{array}{l}\text { Perempu } \\
\text { an } \\
\text { Pendidik } \\
\text { an }\end{array}$ & 62 & 63,9 & 35 & 36,1 & 97 & $\begin{array}{c}10 \\
0\end{array}$ & $\begin{array}{c}(0,41- \\
1,43)\end{array}$ & \\
\hline$\frac{\text { Pendidik }}{\text { an Dasar }}$ & 39 & 73,6 & 14 & 26,4 & 53 & $\begin{array}{c}10 \\
0\end{array}$ & 2,23 & $0,028^{*}$ \\
\hline $\begin{array}{l}\text { Lanjutan/ } \\
\text { PT }\end{array}$ & 65 & 55,6 & 52 & 44,4 & 117 & $\begin{array}{c}10 \\
0\end{array}$ & $\begin{array}{l}(1,04- \\
4,54)\end{array}$ & \\
\hline Pekerjaan & & & & & & & & \\
\hline$\overline{\text { Bekerja }}$ & 47 & 51,6 & 44 & 48,4 & 9 & $\begin{array}{c}10 \\
0\end{array}$ & 0,42 & $0,007 *$ \\
\hline $\begin{array}{l}\text { Tidak } \\
\text { Bekerja }\end{array}$ & 57 & 72,2 & 22 & 27,8 & 79 & $\begin{array}{c}10 \\
0\end{array}$ & $\begin{array}{c}(0,22- \\
0,78)\end{array}$ & \\
\hline
\end{tabular}

*) bermakna pada $\alpha=0,05$

Hasil analisis hubungan antara kelompok umur dengan stigmatisasi bagi ODHA diperoleh bahwa pada kelompok umur dibawah 54 tahun terdapat 101 orang $(62,0 \%)$ memberi stigmatisasi bagi ODHA; dan pada kelompok umur diatas 54 tahun terdapat 3 orang $(42,9 \%)$ memberi stigma kepada ODHA; Hasil uji statistik menggunakan Fisher's Exact Test diperoleh $\mathrm{p}$ value $=0,433$. Maka dapat disimpulkan bahwa Ho gagal ditolak, artinya tidak terdapat hubungan yang signifikan antara kelompok umur dengan stigmatisasi bagi ODHA. Walau tidak ada hubungan yang signifikan, namun hasil analisis lebih lanjut diperoleh pula nilai $\mathrm{OR}=2,17$, yang berarti kelompok umur dibawah 54 tahun mempunyai peluang 2,17 kali untuk memberi stigmatisasi/label buruk bagi ODHA. 
Hasil analisis hubungan antara jenis kelamin dengan stigmatisasi bagi ODHA diperoleh bahwa terdapat 42 orang $(57,5 \%)$ laki-laki memberi stigmatisasi bagi ODHA; terdapat 65 $(63,9 \%)$ orang perempuan juga memberi stigma kepada ODHA. Hasil uji statistik menggunakan Fisher's Exact Test diperoleh $\mathrm{p}$ value $=0,429$. Maka dapat disimpulkan bahwa Ho gagal ditolak, artinya tidak terdapat hubungan yang signifikan antara jenis kelamin dengan stigmatisasi bagi ODHA. Walau tidak ada hubungan yang signifikan, namun hasil analisis lebih lanjut diperoleh pula nilai $\mathrm{OR}=$ 0,77 , yang berarti responden perempuan mempunyai peluang 0,77 kali untuk memberi stigmatisasi/label buruk bagi ODHA.

Hasil analisis hubungan antara pendidikan dengan stigmatisasi bagi ODHA diperoleh bahwa pada responden yang tamat pendidikan dasar (SD dan SLTP) terdapat 39 orang (73,6\%) memberi stigmatisasi bagi ODHA; dan pendidikan lanjutan termasuk PT terdapat 65 orang $(55,6 \%)$ memberi stigma kepada ODHA. Hasil uji statistik menggunakan Fisher's Exact Test diperoleh $\mathrm{p}$ value $=0,028$. Maka dapat disimpulkan bahwa Ho ditolak, artinya terdapat hubungan yang signifikan antara pendidikan dengan stigmatisasi bagi ODHA. Hasil analisis lebih lanjut diperoleh pula nilai $\mathrm{OR}=2,23$, yang berarti responden yang hanya pendidikan dasar (SD dan SLTP) mempunyai peluang 2,22 kali untuk memberi stigmatisasi/label buruk bagi ODHA.

Hasil analisis hubungan antara pekerjaan dengan stigmatisasi bagi ODHA diperoleh bahwa responden yang bekerja baiks ebagai PNS maupun Swasta terdapat 47 orang $(51,6 \%)$ memberi stigmatisasi bagi ODHA; dan yang tidak bekerja terdapat 57 orang $(72,2 \%)$ memberi stigma kepada ODHA. Hasil uji statistik menggunakan Fisher's Exact Test diperoleh $\mathrm{p}$ value $=0,007$. Maka dapat disimpulkan bahwa Ho ditolak, artinya terdapat hubungan yang signifikan antara pekerjaan dengan stigmatisasi bagi ODHA. Hasil analisis lebih lanjut diperoleh pula nilai $\mathrm{OR}=0,42$, yang berarti responden yang tidak bekerja mempunyai peluang 0,42 kali untuk memberi stigmatisasi/label buruk bagi ODHA.

\section{PEMBAHASAN.}

Penelitian yang menggunakan subyek populasi umum semua masyarakat pengunjung ruang rawat inap RSUD Mgr. Gabriel Manek, SVD Atambua pada bulan Mei 2019 memberikan hasil bahwa tingkat penerimaan masyarakat terhadap ODHA di Kabupaten Belu masih sangat memperihatinkan. Terdapat 61,2\% responden memberikan cap/label buruk (stigmatisasi) bagi ODHA. Kondisi ini berbeda dengan di negara lain seperti Kenya yang secara baik digambarkan bahwa tingkat penerimaan masyarakat umum terhadap ODHA sudah cukup tinggi $(60 \%$ bisa menerima guru perempuan yang positif HIV). Perbedaan tingkat penerimaan sebagai manifestasi sikap stigma terhadap ODHA antara masyarakat Kenya dan masyarakat Belu di Indonesia merupakan konsekuensi dari perbedaan situasi epidemi HIV di masingmasing wilayah. Tingginya tingkat penerimaan terhadap ODHA di Kenya bisa dijelaskan berdasarkan fakta bahwa proporsi masyarakat umum yang mengetahui orang berstatus ODHA atau meninggal karena AIDS sudah cukup tinggi. Dengan kata lain, infeksi HIV sudah tidak dipandang sebagai peristiwa langka atau menyimpang dari pengalaman sehari-hari. Hal inilah yang mengurangi sikap stigmatisasi masyarakat terhadap ODHA. Sementara, epidemi HIV dan AIDS di Indonesia pada umumnya (kecuali Papua) dan Belu khususnya masih pada tahap terkonsentrasi. Sehingga sebagian besar masyarakat umum berpandangan bahwa ODHA serta OHIDA merupakan bagian dari anggota masyarakat yang kehilangan kehormatan dan kedudukan (Chiao et al, 2008 dalam Baroya, 2017).

Hasil analisis bivariat menggunakan uji Chi square dan analisis besar risiko menggunakan odds ratio menunjukkan bahwa stigmatisasi terhadap ODHA cukup signifikan berhubungan dengan karakteristik responden. Pendidikan dan pekerjaan secara signifikan berhubungan dengan stigmatisasi bagi ODHA. Dalam penelitian ini ditemukan bahwa responden terbanyak adalah umur dibawah 40 tahun yang berjumlah 148 orang, dan diatas 40 tahun berjumlah 22 orang. Dari kelompok umur kurang dari 40 tahun, terdapat $60,1 \%$ yang memberi stigmatisasi bagi ODHA dan umur lebih dari 40 tahun terdapat 68,2\% memberi stigma kepada ODHA. Penelitian ini tidak sejalan dengan penelitian yang dilakukan oleh Baroya (2017) yang menemukan bahwa 
usia lebih muda mempunyai kemungkinan bersikap menstigma dan mendiskriminasikan ODHA 2 kali lebih besar daripada yang berusia lebih tua.

Selanjutnya jenis kelamin perempuan lebih berstigma terhadap ODHA 0,77 kali lebih besar daripada laki-laki. (OR $=0,77$; 95\% CI $=0,41-1,43)$. Penelitian ini hampir sejalan dengan penelitian dari Baroya (2017) dimana menemukan bahwa perempuan lebih mungkin bersikap menstigma dan mendiskriminasikan ODHA 2 kali lebih besar daripada laki-laki.

Stigmatisasi bagi ODHA juga berbeda menurut tingkat pendidikan. Semakin rendah tingkat pendidikan, kemungkinan bersikap menstigma dan mendiskriminasikan ODHA semakin besar. Dalam penelitian ini ditemukan bahwa pendidikan dasar yang meliputi SD dan SLTP 2,23 kali lebih besar memberikan stigma bagi ODHA dibandingkan dengan mereka yang berpendidikan lanjutan dan perguruan tinggi $(95 \% \mathrm{CI}=1,04-4,54)$.

Penelitian ini hampir sejalan dengan Baroya (2017) yang menemukan bahwa responden yang berpendidikan SD 2,43 kali lebih besar mempunya sikap menstigma dan mendiskriminasikan ODHA dibandingkan dengan mereka yang berpendidikan SLTA atau PT. Demikan juga stigmatisasi bagi ODHA berbeda menurut bekerja tidaknya seseorang. Hasil penelitian ini menunjukkan bahwa orang yang tidak bekerja memiliki kemungkinan 0,42 kali lebih besar untuk memberikan stigmatisasi bagi ODHA dibandingkan dengan orang yang bekerja.

Penelitian ini hampir sejalan dengan penelitian Baroya (2017) dimana ditemukan bahwa orang yang tidak bekerja memiliki kemungkinan yang besar untuk memiliki sikap stigma dan mendiskriminasikan ODHA. Hal ini mungkin disebabkan karena orang yang bekerja tidak sempat memiliki waktu yang kosong untuk diskusi tentang orang lain dibandingkan dengan orang yang tidak bekerja, mereka memiliki waktu yang banyak untuk melakukan diskusi-diskusi topik-topik yang mendiskriminasikan orang lain termasuk ODHA. Adapun keterbatasan dalam penelitian ini diantaranya adalah penyebaran kuisioner tidak didampingi sehingga responden mungkin menjawabnya hanya asal jawab saja dan masih terdapat jawaban kuesioner yang tidak konsisten, karena responden kurang teliti terhadap pertanyaan yang ada.

\section{KESIMPULAN}

Terdapat $61,2 \%$ responden yang memberi stigmatisasi bagi ODHA bagi ODHA di RSUD Mgr Gabriel Manek SVD Atambua; Tidak terdapat hubungan antara umur dengan stigmatisasi bagi ODHA di RSUD Mgr Gabriel Manek SVD Atambua ( $p$ value = 0,433); Tidak terdapat hubungan yang signifikan antara jenis kelamin dengan stigmatisasi bagi ODHA di RSUD Mgr Gabriel Manek SVD Atambua. ( $p$ value = 0,429 ); Terdapat hubungan yang signifikan antara pendidikan dengan stigmatisasi bagi ODHA di RSUD Mgr Gabriel Manek SVD Atambua. Orang yang berpendidikan rendah (SD dan SLTP) memiliki peluang 2,23 kali lebih besar kemungkinan untuk memberikan stigmatisasi bagi ODHA dibandingkan dengan orang yang berpendidikan Lanjutan sampai perguruan tinggi ( $\mathrm{p}$ value $=0,028 ; \mathrm{OR}=2,23$; 95\% CI $=1,04-4,45)$; Terdapat hubungan yang signifikan antara pekerjaan dengan stigmatisasi bagi ODHA di RSUD Mgr Gabriel Manek SVD Atambua. Orang yang tidak bekerja memiliki kemungkinan 1,42 kali memberikan stigmatisasi bagi ODHA dibandingkan dengan orang yang bekerja ( $\mathrm{p}$ value $=0,007 ; \mathrm{OR}=1,42 ; 95 \% \mathrm{CI}=0,22$ 0,78. Disarankan kepada Pihak manajemen rumah sakit agar mengembangkan pola-pola penyuluhan HIV AIDS di rumah sakit dengan metode penyuluhan sentral sehingga semua pengunjung bisa terpapar tentang informasi HIV AIDS agar tidak melakukan stigmatisasi kepada ODHA. Untuk peneliti selanjutnya, agar melakukan penelitian serupa dengan variabel yang lebih luas. Judul yang ditawarkan adalah: "analisis faktor-faktor yang berhubungan dengan stigmatisasi bagi ODHA"

\section{KEPUSTAKAAN}

Adhi Djuanda. 2005. Ilmu Penyakit Kulit dan Kelamin. Jakarta: Balai Penerbit FKUI.

Aziz Alimul Hidayat. 2007. Riset Keperawatan dan Teknik Penulisan IlmiahJakarta: Salemba Medika.

Baroya, N. (2017). Prediktor Sikap Stigma dan Diskriminasi Terhadap Orang Dengan HIV dan AIDS (ODHA) di Kabupaten Jember. Jurnal IKESMA Volume 13 Nomor 2 September 2017. Diunduh dari 
http:/google.com. Tanggal 20 Juni 2019

Berek, P. A. L., Be, M. F., Rua, Y. M., \& Anugrahini, C. (2018). Hubungan Jenis Kelamin dan Umur Dengan Tingkat Pengetahuan Remaja Tentang HIV/AIDS di SMAN 3 Atambua, Nusa Tenggara Timur, 1-13.

Brunner \& Suddarth. 2014. Keperawatan Medikal Bedah. Jakarta : Buku Kedokteran EGC.

Christanto. 2014. Kapita Selekta Kedokteran. Jakarta : Media Aesculapius.

Clevo Rendy. 2012. Asuhan Keperawatan Medikal Bedah dan Penyakit Dalam.Yogyakarta : Nuha Medika.

Fauk, N. K., Sukmawati, A. S., Berek, P. A. L., Ernawati, Kristanti, E., Wardojo, S. S. I., ... Mwanri, L. (2018). Barriers to HIV testing among male clients of female sex workers in Indonesia. International Journal for Equity in Health, 17(1), 110. http://doi.org/10.1186/s12939-0180782-4

Kurniawati Dian, N., \& Nursalam. (2009). Asuhan Keperawatan pada Pasien Terinfeksi HIV/AIDS.

Notoadmojo, S, 2009. Pendidikan dan Promosi Kesehatan. Jakarta : Rineka Cipta.

Nursalam. 2007. Asuhan Keperawatan Pada Pasien Terinfeksi HIV/AIDS.Jakarta: Salemba Medika.

Nursalam. 2013. Metodologi Penelitian Ilmu Keperawatan. Jakarta : SalembaMedika.

Soekidjo Notoatmodjo. 2005. Metodologi Penelitian Kesehatan. Jakarta :Rineka Cipta.

Widoyono. 2008. Penyakit Tropis Epidemiologi, Penularan, Pencegahan \& Pemberantasanya. Semarang : Erlangga.

Wilkins. 2006. Lecture Notes Penyakit Infeksi. Jakarta : Erlangga.
Yuli Peritiowati. 2014. Imunologi Diagnosis dan Teknik Biologi Molekuler. Yogyakarta : Nuha Medika. 